\title{
Kajian Pengelolaan Ekowisata di Desa Bendosari Kecamatan Pujon Kabupaten Malang
}

\author{
Antonius Kasa Rajaํㅜ ${ }^{1}$ Rizki Alfian ${ }^{1}$, Riyanto Djoko ${ }^{1}$ \\ 1. Program Studi Arsitektur Lanskap, Fakultas Pertanian, Universitas Tribhuwana Tunggadewi, \\ Jl. Telagawarna, Tlogomas, Malang, Indonesia \\ *Email : akhasradja17@gmail.com
}

\begin{abstract}
Study of Ecotourism Management in Bendosari Village, Pujon District, Malang Regency. The concept of ecotourism is one alternative to develop an area into a tourist destination that pays attention to environmental sustainability by utilizing the potential of natural and cultural resources of the local community. Therefore, the existence of the concept of ecotourism can ensure the preservation of nature and its ecosystem. This study aims to: 1) Identify the potential and problems in Bendosari Village, Pujon District, Malang Regency, 2) Identify the feasibility level of ecotourism in Bendosari Village, Pujon District, Malang Regency, and 3) Develop a strategy for developing ecotourism areas in Bendosari Village, Pujon District, Malang Regency. Collecting data in this study using survey methods (observations and interviews), literature study and documentation methods. Analysis of the data used, namely: first qualitative descriptive analysis, second feasibility analysis based on the Guidelines (ADO-ODTWA) of the Director General of PHKA 2003 and the last is SWOT analysis. The results showed that: 1) The potential of natural resources in the ecotourism area of Bendosari Village, namely: the potential for flora and fauna, the potential for nature tourism, the potential for educational tourism, the potential for craft tourism and the potential for cultural tourism. The problems of ecotourism in Bendosari Village include the low quality of human resources, limited funds and the role of the Malang Regency Government which has not been active. 2) Ecotourism in Bendosari Village is feasible to be developed as a tourist attraction with the results of the Guideline assessment (ADO-ODTWA) of 82.71\%. 3) The strategy for developing Ecotourism in Bendosari Village is an expansion strategy (supporting offensive strategies) with alternative strategies that include: maximizing the development of ecotourism packages, empowering local communities in ecotourism activities, increasing security in tourist attractions, and maximizing tourism potential management.
\end{abstract}

\section{Keywords: Ecotourism, Feasibility Study, Management, SWOT}

\section{Pendahuluan}

Menurut (TIES (The International Ecotourism Society), 2015), ekowisata merupakan kegiatan wisata yang terlatih serta memuat unsur pendidikan yang dikemas secara baik, sebagai salah satu bagian upaya ekonomi, yang meninjau peninggalan adat istiadat, keterlibatan, serta ketenteraman masyarakat setempat sebagai usaha pelestarian lingkungan dan SDA. Wisata alam dapat diartikan wujud aktivitas pariwisata serta rekreasi yang memanfaatkan potensi ekosistem dan SDA, baik yang bersifat alami ataupun setelah adanya campur tangan manusia (Siregar, 2017). Menurut Tosun dan Timothy (2003) ditegaskan bahwa aspek penting dari pembangunan pariwisata berkelanjutan adalah penekanan pada pariwisata berbasis masyarakat. Pendekatan ini lebih mengutamakan pada potensi masyarakat lokal untuk berpartisipasi dalam perencanaan dan pengembangan destinasi wisata. Dengan adanya partisipasi masyarakat, pariwisata secara langsung dapat memberikan manfaat bagi masyarakat setempat. Melalui prinsip-prinsip berbasis masyarakat, hubungan yang baik dapat terjalin antara pengelola dan masyarakat. Selain itu, melalui pembangunan berbasis masyarakat, kesadaran masyarakat terhadap alam akan meningkat, sehingga mengurangi dampak negatif yang telah terjadi.

Jawa Timur merupakan salah satu provinsi yang memiliki banyak tempat wisata di setiap kabupaten dan kota, sebagian besar berada di Kabupaten Malang khususnya Desa Bendosari yang memiliki potensi wisata alam yang masih alami, tetapi sebenarnya belum adanya pihak yang tertarik untuk mengembangkan kawasan ekowisata ini secara optimal, yang menjadikan lokasi tersebut belum terlihat sebagai objek wisata. Selain itu, kemajuan destinasi wisata di Kabupaten Malang menimbulkan 
permasalahan baru yaitu pengembangan wisata tidak serasi dengan pengembangan ekonomi. Sebagai destinasi wisata di Jawa Timur, Kabupaten Malang sebenarnya mempromosikan potensi alamnya yang indah dan sejuk. Oleh sebab itu, pengembangan pariwisata dalam rangka peningkatan perekonomian perlu juga memperhatikan upaya lingkungan.

Berdasarkan permasalahan tersebut, Pemerintah Daerah Malang telah memutuskan untuk mengembangkan wilayah Malang Raya menjadi pusat wisata untuk pengembangan desa wisata pertanian dan ekowisata (Musrenbang, 2014). Pembangunan ekowisata semacam ini bermaksud untuk mengelola SDA dan budaya tanpa mengganggu konsep ekologi lingkungan wisata itu sendiri serta mampu meningkatkan potensi wisata lokal hingga ke tingkat desa.

Berdasarkan latar belakang tersebut, daya tarik wisata alam merupakan segala untuk mengkaji lebih jauh mengenai keunikan, keindahan, keaslian, tarik wisata, keselamatan, dan sarana wisata yang menjadi sasaran atau tujuan kunjungan wisatawan. Dengan demikian, penelitian ini diharapakan dapat menjadi rekomendasi kampung ekowisata di Desa Bendosari Kecamatan Pujon Kabupaten Malang.

Adapun tujuan dari penelitian ini meliputi: 1) mengidentifikasi potensi dan masalah di Desa Bendosari Kecamatan Pujon Kabupaten Malang, 2) mengidentifikasi tingkat kelayakan ekowisata di Desa Bendosari Kecamatan Pujon Kabupaten Malang dan 3) menyusun strategi pengembangan kawasan ekowisata di Desa Bendosari Kecamatan Pujon Kabupaten Malang.

\section{Metode Penelitian}

Penelitian dilaksanakan di Desa Bendosari, Kecamatan Pujon, Kabupaten Malang (Gambar 1). Waktu pelaksanaan penelitian, dimulai pada bulan Januari sampai Februari 2021.

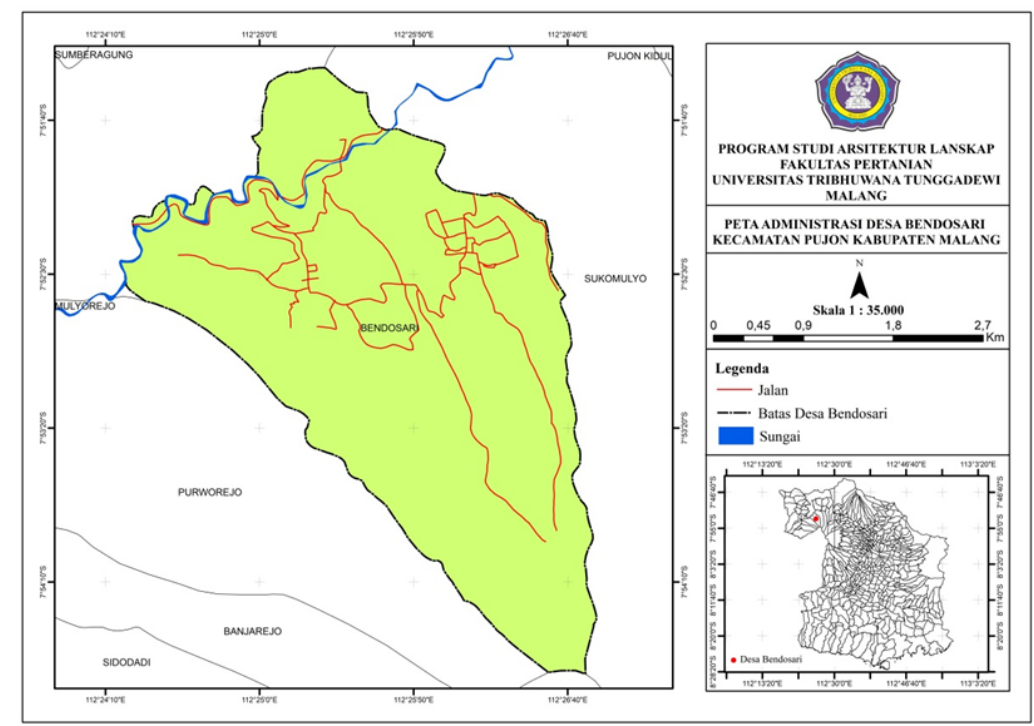

Gambar 1. Lokasi Penelitian

Pengelolaan ekowisata yang dimaksudkan dalam penelitian ini meliputi daya tarik, aksesibilitas, akomodasi, sarana dan prasarana penunjang sesuai pedoman ADO-ODTWA (Analisis Daerah Operasi Objek dan Daya Tarik Wisata Alam) Dirjen PHKA 2003. Jenis dan sumber data yang digunakan dalam penelitian adalah data primer (jenis flora dan fauna, serta peninjauan fisik objek panorama alam) dan data skunder (kondisi geografis lokasi penelitian).

Metode pengumpulan data menggunakan metode survey, metode kepustakaan dan metode dokumentasi. Sedangkan analisa data menggunakan analisis deskriptif kualitatif yang bertujuan untuk memahami potensi dan masalah di kawasan ekowisata Desa Bendosari Kecamatan Pujon Kabupaten Malang, analisis studi kelayakan menggunakan standar penilaian berdasarkan peraturan ADO-ODTWA 
(Analisis Daerah Operasi Objek dan Daya Tarik Wisata Alam) Dirjen PHKA tahun 2003 sesuai dengan nilai yang telah ditetapkan untuk tiap-tiap kriteria. Perhitungan untuk masing-masing kriteria tersebut menggunakan tabulasi dimana angka-angka diperoleh dari hasil penilaian responden dan peneliti yang nilai bobotnya berpedoman pada penilaian ADO-ODTWA Dirjen PHKA 2003. Adapun unsur yang akan dinilai dan di catat adalah daya tarik, aksesibilitas, akomodasi, sarana dan prasarana penunjang. Kriteria daya tarik diberi bobot 6 karena merupakan faktor utama seseorang melakukan kegiatan wisata. Aksesibilitas diberi bobot 5 karena merupakan faktor penting yang mendukung wisatawan untuk melakukan kegiatan wisata. Akomodasi dan sarana/prasarana diberi bobot 3 karena merupakan faktor penunjang dalam kegiatan wisata, serta analisis SWOT yang bertujuan untuk menyususn alternatif strategi pengembangan ekowisata yang lestari pada kawasan ekowisata di Desa Bendosari Kecamatan Pujon Kabupaten Malang.

\section{Hasil Dan Pembahasan}

\subsection{Potensi Dan Permasalahan Ekowisata Di Desa Bendosari}

Potensi ekowisata ialah ketentuan utama yang harus ada di setiap lokasi wisata, maka dari itu potensi yang ada di salah satu area wisata bisa berbeda di masing-masing kawasan, semakin indah dan unik potensi yang ada di salah satu area ekowisata maka pengunjung bertambah tertarik untuk menobatkan kawasan tersebut sebagai tujuan wisata.

Hasil observasi menunjukan bahwa potensi yang ada di area ekowisata Desa Bendosari ialah potensi flora dan fauna, potensi wisata alam, wisata pendidikan, wisata kerajinan dan wisata budaya. Dari perpaduan alam, flora dan fauna, keadaan kemasyarakatan serta adat istiadat yang tetap terjaga sangat menarik untuk dipelihara sebagai area ekowisata yang ramah lingkungan. Adapun potensi sumber daya di Desa Bendosari sebagai berikut: 1) Potensi Flora dan fauna, Desa Bendosari yang terletak di daerah pegunungan, memiliki vegetasi yang spesifik sesuai dengan iklim dan ketinggian lahannya. Fauna yang dominan di Desa Bendosari yaitu tanaman pohon keras seperti, jati (Tectona grandis), dan pinus (Casuarina equisetifoli), 2) Potensi wisata alam: Coban Grojogan Sewu, Alas Pujon Coban Sadang, Hutan pinus Bendosari, Taman kemesraan, Wisata petik apel, 3) Potensi Wisata Pendidikan PLTMH (Pembangkit Listrik Tenaga Mikro Hidro), Wisata pendidikan peternakan sapi perah, 4) Potensi Wisata Kerajinan Rotan dan Wisata ritual kerbau.

Objek wisata alam di Desa Bendosari Kecamatan Pujon Kabupaten Malang kini dikelola oleh banyak pihak, diantaranya Perum Perhutani (Perusahaan Hutan Negara Indonesia), Dinas Pariwisata dan swasta. Partisipasi masyarakat dalam pengelolaan ekowisata di area ini masih terbatas berupa agrowisata, pengelolaan tiket masuk kawasan wisata, menjaga kebersihan area wisata, penanganan parkir, membuka toko atau warung, kafe dan penyediaan home stay.

Potensi ekowisata yang cukup besar di Desa Bendosari ini ternyata belum dapat dikembangkan secara optimal, dikarenakan adanya permasalahan ekowisata yang menghambat pengembangan potensi ekowisata tersebut. Hasil wawancara dengan Kepala Desa Bendosari menunjukan bahwa permasalahan ekowisata di Desa Bendosari diantaranya meliputi:

1. Kurangnya kualitas SDM tenaga pengelola menghambat peningkatan potensi Kampung Ekowisata Bendosari.

2. Dana terbatas.

3. Pemerintah Kabupaten Malang tidak aktif membantu pengadaan sarana dan prasarana aktivitas ekowisata, juga tidak memberikan anggaran dana yang diprakarsai oleh Pemerintah Desa Bendosari.

\subsection{Penilaiaan Objek dan Daya Tarik Ekowisata Desa Bendosari}

Unsur penilaian pada kawasan ekowisata Desa Bendosari yaitu pesona kawasan ekowisata, aksesibilitas agar dapat menjangkau area wisata, akomodasi yang terdapat di seputar kawasan ekowisata serta sarana dan prasarana penunjang untuk membantu kemajuan area ekowisata. Daya tarik area wisata ialah kondisi penting yang membuat area tersebut menarik keinginan pengunjung untuk melaksanakan aktivitas wisata. Menurut Devy dan Soemanto (2017) dengan adanya destinasi serta pesona wisata ialah perihal utama pada salah satu aktivitas wisata sebab aspek dasar yang 
mengundang wisatawan mengunjungi destinasi wisata merupakan kemampuan serta pesona yang dimiliki wisata tersebut.

Kawasan Ekowisata Desa Bendosari memiliki kemampuan daya tarik sangat memadai guna mempengaruhi keinginan wisatawan untuk mengunjungi ke kawasan tersebut. Pesona yang ada pada kawasan Ekowisata Desa Bendosari diamati dari keanekaragaman SDA yang dominan diantaranya tumbuhan dan hewan, bukit, keindahan air terjun dan sungai, lalu aktivitas wisata yang bisa dilakukan didalam area seperti aktivitas berenang di dekat air terjun Grojogan Sewu, menikmati pemandangan alam, mengamati flora dan fauna, melakukan studi riset/observasi, aktivitas olahraga dan berkemah. Selanjutnya daya tarik seperti kebersihan, kenyamanan dan keamanan sebagaimana jauh dari keributan dan udara yang sejuk serta bersih juga termasuk pesona pada kawasan Ekowisata Desa Bendosari. Tiap-tiap daya tarik ini memiliki skor yang akan menentukan jumlah apakah lokasi tersebut mampu menarik keinginan pengunjung.

Hasil penilaian unsur daya tarik menunjukan nilai yang didapatkan adalah 900, nilai tersebut didapatkan dari hasil multiplikasi antara nilai dengan bobot dari masing-masing sub kriteria, selanjutnya di jumlahkan semuanya, yang mana unsur karakteristik SDA memperoleh skor 30 karena di area terdapat lima kriteria diantaranya keunikan bukit, tumbuhan, hewan, Adat istiadat/ kebudayaan dan sungai serta air terjun.

Untuk kriteria banyaknya SDA yang menonjol didapatkan nilai 25 karena di area ekowisata ditemukan empat aspek diantaranya flora dan fauna, bukit serta air terjun. berikutnya untuk penilaian aktivitas wisata yang bisa dilaksanakan terdapat lima aspek diantaranya menghayati keelokan alam, mengamati tumbuhan dan hewan, penelitan/riset, kegiatan olahraga dan berkemah maka skor yang didapatkan yaitu 30. Evaluasi kebersihan kawasan objek wisata ada tiga aspek ialah bebas dari limbah industri, tidak adanya limbah, jauh dari kebisingan, dan tidak adanya coret-coretan, maka nilai yang didapatkan adalah 20. Selanjutnya pada penilaian keamanan lokasi ada dua komponen diantaranya tidak adanya penggundulan hutan serta tidak adanya perampokan maka skor yang didapatkan adalah 15 dan untuk penilaian kenyamanan lokasi terdapat lima aspek yaitu udara yang bersih dan sejuk, bebas dari bau yang menggangu, bebas dari keramaian, tidak ada lalu lintas yang meghalangi dan tersedianya sarana dan prasarana maka nilai didapatkan adalah 30.

Perjalanan menuju kawasan Ekowisata Desa Bendosari bisa dijangkau dengan jangka waktu \pm 45 menit dari pusat Kota Malang. Pengunjung bisa memanfaatkan angkutan umum (bus) yang melewati Desa Bendosari melalui jalur Malang-Kediri/Jombang dengan biaya sebesar Rp. 10.000,-. Jarak dari pusat kota menuju ke kawasan ekowisata $\pm 30 \mathrm{~km}$. Jenis jalur menuju area Ekowisata Desa Bendosari yaitu jenis jalur aspal yang lebarnya $>3 \mathrm{~m}$.

Hasil penilaian komponen aksesibilitas menunjukan bahwa nilai total yang didapatkan adalah 525, skor tersebut didapatkan dari penilaian setiap sub kriteria yang mana pada penilaian keadaan jalur menuju kawasan Ekowisata Desa Bendosari membuktikan kondisi jalur yang baik maka skor yang didapatkan 30 dan jenis jalur aspal dengan lebar $>3 \mathrm{~m}$ maka skor yang didapatkan 30 . Area wisata Desa Bendosari sedikit berjauhan dengan pusat kota Malang yaitu $\pm 30 \mathrm{~km}$, maka skor yang didapatkan 25, dan dari pusat kota Malang menuju area Ekowisata Desa Bendosari cuma diperlukan waktu 45 menit maka skor yang didapatkan 30. Keadaan ini memperjelas kondisi area ekowisata yang sangat bagus untuk dijangkau. Kondisi ini sejalan dengan penjelasan MacKinnon et. al., 1990. Dalam Ginting, et. al., 2015. yang dijelaskan dua dari sejumlah unsur yang membangun salah satu area yang memukau minat wisatawan yaitu lokasinya mudah dijangkau, sangat dekat dari pusat wisata utama atau pusat kota atau jauh dari bandar udara internasional dan juga perjalanan menuju area tersebut apakah nyaman dan mudah, perlu sedikit usaha, berbahaya atau sulit. Salah satu keadaan yang membatasi dukungan untuk aksesibilitas ini yaitu jarak menuju lokasi Desa Bendosari yang bisa di katakan cukup jauh dengan kondisi jalan yang cukup menanjak. Tetapi apabila dilihat dari sisi lainya kondisi tersebut membuat situasi yang cukup menantang dan menyenangkan bagi wisatawan yang harus sedikit berusaha untuk mendatangi area Ekowisata Desa Bendosari, tetapi dapat dipastikan jalur yang tersedia aman untuk dilewati. 
Ketersediaan fasilitas disuatu area wisata yaitu aspek dasar untuk wisatawan yang ingin bermalam diarea tersebut. Berdasarkan Mackinnon et. al., 1990. Dalam Ginting, et. al., 2015. menjelaskan akomodasi itu ialah suatu unsur yang mampu menarik minat wisatwan dalam melaksanakan suatu perjalanan wisata. Ketersediaan fasilitas di area wisata sangat membantu wisatawan apabila wisatawan hendak menetap di tempat yang dikunjunginya. Tetapi seumpama tidak ada akomodasi di kawasan wisata, wisatawan bisa mencari fasilitas yang tidak jauh dari kawasan wisata. Area Ekowisata Desa Bendosari telah sediakan akomodasi pada kawasan tersebut. Akomodasi yang berada di Desa Bendosari berupa home stay yang di sediakan oleh warga setempat dan cottage yang berada pada lokasi wisata Alas Pujon Kidul.

Penilaian untuk akomodasi di seputar lokasi diperoleh skor total yang didapatkan yaitu 180, skor tersebut diperoleh dari penilaian akomodasi yang terdapat diseputar lokasi dalam radius $15 \mathrm{~km}$ dari tujuan, dari pertimbangan ini sehingga diketahui beberapa penginapan dan hotel yang lebih dari 30 penginapan, maka skor yang didapatkan 30 dan total keseluruhannya lebih dari 100 kamar maka skor yang diperoleh juga 30. Akomodasi yang disediakan oleh pihak Desa Bendosari meliputi home stay dan cottage/pondok. Sedangkan akomodasi hotel dapat diakses pada desa sekitar Desa Bendosari yang berada dalam satu kecamatan diantaranya Desa Pujon Lor, Desa Pujon Kidul, Desa Ngabab dan Desa Pandesari. Akomodasi sekitar kawasan Ekowisata Desa Bendosari sangat mencukupi, situasi ini disebabkan kawasan objek wisata berdekatan dengan Kota Batu dan Kota Malang maka jangkauan untuk mencapai kawasan sangat nyaman serta memiliki akomodasi yang cukup di kota. Meskipun fasilitas begitu mencukupi diseputar lokasi, akan lebih baik apabila fasilitas juga tersedia di lokasi, situasi ini tentu memberikan nilai tambah.

Sarana dan prasana di seputar area ekowisata ialah suatu unsur pesona yang sangat diperlukan dalam ekowisata, situasi ini berpengaruh pada perkembangan salah satu tujuan wisata. Evaluasi tentang sarana dan prasarana pendukung pada area Ekowisata Desa Bendosari diperoleh nilai 240, hasil ini didapatkan dari penilaian sarana dan prasarana penunjang yang ditemukan diseputar area Ekowisata Desa Bendosari dengan jangkauan $10 \mathrm{~km}$ dari tujuan wisata ditemui prasarana pendukung diantaranya ketersediaan koneksi telepon, listrik serta air minum maka skor yang diperoleh adalah 40. Sementara itu untuk sarana penunjang juga sangat mencukupi diantaranya tersedia warung, toko cendera mata serta angkutan umum maka nilai yang diperolehi 40. Sarana dan prasarana di seputar area Ekowisata Desa Bendosari cukup lenkap karena letak lokasinya tidak jauh dari pusat kota.

\subsection{Analisa Kelayakan Objek dan Daya Tarik Ekowisata Desa Bendosari}

Penelitian ini dilaksanakan dengan wawancara dan eksplorasi langsung di area Ekowisata Desa Bendosari Kecamatan Pujon Kabupaten Malang untuk memahami sumberdaya yang ada, dengan menilai sebagian kriteria atau unsur yang meliputi daya tarik, aksesibilitas, akomodasi serta sarana dan prasarana pendukung dalam membantu kemajuan area ekowisata. Dari hasil yang di diperoleh selanjutnya di analisis untuk dipertimbangkan apakah area Ekowisata Desa Bendosari cukup, kurang cukup atau tidak cukup untuk dikembangkan. Hasil penilaian atas aspek-aspek pada area Ekowisata Desa Bendosari dapat diamati pada tabel 1 berikut.

Tabel 1. Hasil Penilaian Objek dan Daya Tarik Ekowisata Desa Bendosari

\begin{tabular}{clcccc}
\hline No & \multicolumn{1}{c}{ Kriteria } & Skor Maks & Skor Total & Indeks & Keterangan \\
\hline 1 & Daya Tarik & 1080 & 900 & 83.33 & Layak \\
2 & Aksesibilitas & 600 & 525 & 87.50 & Layak \\
3 & Akomodosi & 180 & 180 & 100.00 & Layak \\
4 & Sarana dan Prasarana & 300 & 240 & 80.00 & Layak \\
Tingkat Kelayakan & & & 87.71 & Layak \\
\hline
\end{tabular}

Sumber: Data Primer, 2021 
Berdasarkan Tabel 1 menunjukkan bahwa kawasan Ekowisata Desa Bendosari layak dikembangkan. Sesuai dengan hasil penilaian maka kawasan Ekowisata Desa Bendosari memiliki potensi pengembangan yang baik dengan skor indeks sebesar $87,71 \%$. Situasi ini sejalan dengan penjelasan Sihite et. al (2018) yang menjelaskan bahwa tingkatan kelayakan $>66,6 \%$ dapat digolongkan sebagai layak pengembangan. Hasil evaluasi keempat kriteria Ekowisata di Desa Bendosari mempunyai skor indeks kelayakan yang berbeda. Nilai indeks standar daya tarik sebesar $83,33 \%$ dengan deskripsi cocok, nilai indeks standar aksesibilitas 87,50\% dengan deskripsi layak dikembangkan, dan nilai indeks standar $100,00 \%$ dengan informasi layak dikembangkan, fasilitas dan standar. Nilai indeks infrastruktur adalah $80,00 \%$ yang memiliki informasi yang layak untuk dikembangkan.

\subsection{Strategi Pengembangan Kawasan Ekowisata Desa Bendosari dengan Analisis SWOT}

Sesuai dengan potensi dan masalah yang ada dan hasil analisis kelayakan obyek dan daya tarik ekowisata Desa Bendosari, kemudian melakukan analisis SWOT (kekuatan, kelemahan, peluang, dan ancaman). Analisis SWOT ini adalah metode untuk mengenali masalah yang bersumber pada kemampuan/kekuatan serta kelemahannya untuk mengatasi dan menghadapi kesempatan serta tantangan/ancaman. Sehingga hasil analisis tersebut bisa dijadikan dasar untuk pembangunan ekowisata di Desa Bendosari kedepannya. Diharapkan dengan analisis SWOT, pembangunan ekowisata bisa lebih terkonsentrasi serta sejalan dengan kemampuan yang ada.

Melalui analisis SWOT ini, semua elemen yang terkait dengan ekowisata dibagi menjadi dua kategori, yaitu faktor internal serta faktor eksternal. Faktor internal yaitu kelebihan dan kekurangan, sedangkan faktor eksternal yaitu peluang dan tantangan/ancaman. Berdasarkan informasi dan penelitian di lokasi ini, didapatkan deskripsi analisis SWOT.

Selanjutnya uraian dari analisis SWOT dimasukan ke dalam strategi pengembangan berdasarkan kombinasi antara kemampuan dan kesempatan menjadi strategi S-O, kemampuan dan ancaman menjadi strategi S-T, kelemahan dan peluang menjadi strategi W-O, serta kelemahan dan ancaman menjadi strategi W-T. Berdasarkan hasil penelitian dapat ditemukan rating dan bobot aspek strategi internal dan eksternal kawasan Ekowisata Desa Bendosari, dimana pembobotan dilakukan dengan tujuan aspek-aspek tersebut dapat memberikan pengaruh terhadap faktor strategis. Sedangkan tujuan rating adalah memberikan skala mulai dari 4 sampai 1 berdasarkan pengaruh faktor tersebut terhadap pengembangan kawasan Ekowisata Desa Bendosari, dan memperoleh total skor pembobotan kawasan Ekowisata Desa Bendosari. Faktor-faktor strategis internal dan eksternal diberikan bobot dan nilai (rating) berdasarkan pertimbangan profesional (Professional Judgment). Pertimbangan professional merupakan pemberian pertimbangan berdasarkan keahliannya, kompeten dengan sesuatu yang dipertimbangkannya. Pertimbangan professional pada analisis faktor strategi internal eksternal dilakukan berdasarkan hasil wawancara mendalam dengan aparat Desa Bendosari. Hasil penelitian menunjukan nilai total masing-masing faktor terdiri dari, faktor kekuatan sebesar 1,993, faktor kelemahan sebesar 1,353, faktor peluang sebesar 2,205 dan faktor ancaman sebesar 1,921. Nilai total ini menunjukkan bagaimana kawasan Ekowisata Desa Bendosari bereaksi terhadap aspek-aspek strategi internal dan ekternalnya.

Dari uraian analisis SWOT diatas, bahwa pada kerangka strategi keseluruhan, cara utama yang bisa direncanakan yaitu memanfaatkan waktu sebaik-baiknya, menerapkan antisipasi dan penanggulangan ancaman, memanfaatkan kekuatan sebagai bentuk operasi dasar dan mengelola sebaik mungkin dengan berupaya untuk meminimalisir serta menghapuskan kekurangan yang masih ada. Dilihat dari hasil penilaian ini maka kawasan Ekowisata Desa Bendosari memiliki kekuatan yang dominan dibanding kelemahannya dan peluang yang lebih besar dibanding ancamannya dengan nilai sebagai berikut:

1. Kekuatan - Kelemahan (faktor internal) : $1,993-1,353=0,640$

2. Peluang - Ancaman (faktor eksternal) : 2,205 - 1,921 $=0,283$

Apabila nilai-nilai tersebut dimasukkan dalam Matrix Grand Strategy terlihat posisi pengembangan kawasan Ekowisata Desa Bendosari berada di posisi Strategi Expansion, yaitu memanfaatkan seoptimal mungkin kekuatan dan peluang yang dimiliki. Untuk lebih jelasnya dapat disajikan pada gambar 2 berikut. 


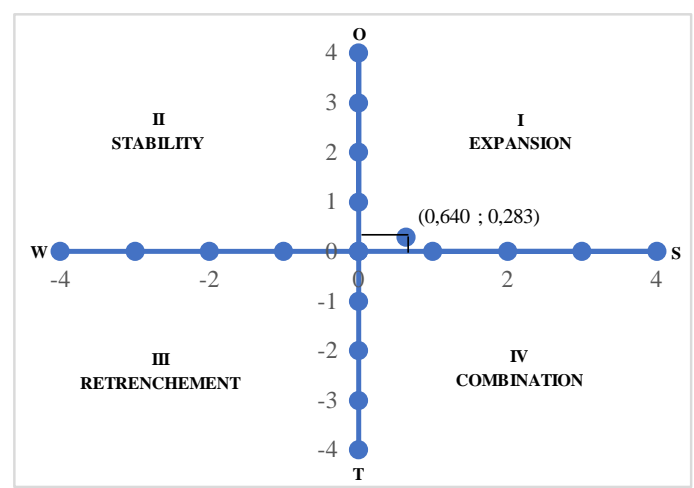

Gambar 2. Grand Strategy Matrix Pengembangan Area Ekowisata Desa Bendosari

Berdasarkan gambar 2 terlihat bahwa titik potong $(0,640 ; 0,283)$ berada pada kuadran I, yang mana kondisi ini bisa diadakan dengan menggunakan kekuatan dan peluang agar bisa mengembangkan kemajuan kawasan Ekowisata Desa Bendosari. Selanjutnya menggunakan kekuatan yang dimiliki seperti terdapat beberapa keunikan sumber daya alam, Terdapat kesenian dan budaya khas desa, atraksi wisata yang beragam, suasana objek wisata yang bersih dan nyaman, keadaan jalan yang baik, akomodasi wisata sangat memadai, dan ada manajemen pengelolaan wisata (Pokdarwis), serta peluang yang dimiliki antara lain otonomi daerah memberikan keleluasaan untuk mengembangkan potensi wisata, meningkatkan pendapatan masyarakat, dekat dengan wisata Kota Batu, didukung oleh jaringan transportasi yang memadai, pengunjung tidak hanya berasal dari Kota Malang. Strategi yang dapat diterapkan dalam kondisi ini adalah strategi expansion (mendukung strategi ofensif). Dengan demikian, arahan strategi untuk pengembangan Ekowisata Desa Bendosari dapat dijabarkan pada tabel berikut.

Tabel 2. Bagan Pengembangan Kawasan Ekowisata Desa Bendosari berdasarkan tahapan pencocokan analisis SWOT

\begin{tabular}{|c|c|c|}
\hline Faktor Internal & $\begin{array}{l}\text { Kekuatan (S) } \\
\text { - Terdapat beberapa keunikan } \\
\text { sumber daya alam } \\
\text { - Terdapat kesenian dan budaya } \\
\text { khas desa } \\
\text { - Atraksi wisata yang beragam } \\
\text { - Suasana objek wisata yang } \\
\text { bersih } \\
\text { - Kondisi jalan yang baik } \\
\text { - Akomodasi wisata sangat } \\
\text { memadai } \\
\text { - Ada management pengelolaan } \\
\text { wisata (Pokdarwis) } \\
\text { - Terdapat sarana dan } \\
\text { prasarana penunjang wisata }\end{array}$ & $\begin{array}{l}\text { Kelemahan (W) } \\
\text { - Jangkauan yang cukup jauh } \\
\text { dari pusat Kota Malang } \\
\text { - Rawan bencana longsor } \\
\text { - Rendahnya kualitas sumber } \\
\text { daya manusia } \\
\text { - Rawan penyakit berbahaya } \\
\text { (Covid-19) } \\
\text { - Promosi wisata yang kurang } \\
\text { baik } \\
\text { - Keterbatasan dana }\end{array}$ \\
\hline \begin{tabular}{l}
\multicolumn{1}{c}{ Peluang $(0)$} \\
- Otonomi daerah memberikan \\
keleluasaan untuk \\
mengembangkan potensi \\
wisata \\
- Meningkatkan pendapatan \\
masyarakat \\
- Dekat dengan wisata Kota \\
Batu \\
- Didukung oleh jaringan
\end{tabular} & $\begin{array}{l}\text { Strategi SO } \\
\text { - menggunakan otonomi daerah } \\
\text { dalam mengelola kemampuan } \\
\text { alam serta objek wisata yang } \\
\text { menarik. } \\
\text { - Memaksimalkan pengelolaan } \\
\text { potensi wisata untuk } \\
\text { meningkatkan pendapatan } \\
\text { masyarakat } \\
\text { - Mengembangkan keamanan di }\end{array}$ & \begin{tabular}{l}
\multicolumn{1}{c}{ Strategi WO } \\
- Mengadakan kerjasama \\
antara investor dengan \\
pemerintah untuk \\
mendukung peningkatan \\
wisata yang aman dari \\
penyakit Covid 19. \\
- Jangkauan yang cukup jauh \\
dari Pusat Kota Malang, \\
Hal itu dapat dilakukan
\end{tabular} \\
\hline
\end{tabular}




\begin{tabular}{|c|c|c|}
\hline $\begin{array}{l}\text { transportasi yang memadai } \\
\text { - Pengunjung tidak hanya } \\
\text { berasal dari Kota Malang }\end{array}$ & $\begin{array}{l}\text { kawasan ekowisata guna } \\
\text { menjaga kenyamanan serta } \\
\text { menarik pengunjung. } \\
\text { - Menguatkan penduduk lokal } \\
\text { dalam aktivitas ekowisata } \\
\text { - Memaksimalkan pembangunan } \\
\text { paket ekowisata }\end{array}$ & $\begin{array}{l}\text { dengan memperbaiki jalan } \\
\text { yang rusak dan didukung } \\
\text { oleh akomodasi dan daya } \\
\text { tarik wisata Kota Batu. } \\
\text { - Penyuluhan tentang usaha- } \\
\text { usaha yang terkait dengan } \\
\text { wisata terhadap SDM } \\
\text { setempat. } \\
\text { - Meningkatkan promosi } \\
\text { wisata }\end{array}$ \\
\hline $\begin{array}{l}\text { Ancaman (T) } \\
\text { - Sistem pengelolaan yang } \\
\text { dilakukan pemerintah Daerah } \\
\text { kurang maksimal } \\
\text { - Persaingan dengan obyek } \\
\text { wisata lain } \\
\text { - Dampak negatif dari kegiatan } \\
\text { ekowisata (sampah dan } \\
\text { kegiatan yang merusak } \\
\text { ekosistem) } \\
\text { - Alih fungsi lahan }\end{array}$ & $\begin{array}{l}\text { Strategi ST } \\
\text { - Meningkatkan keunikan sumber } \\
\text { daya alam dan potensi wisata } \\
\text { untuk menghadapi persaingan } \\
\text { antar objek wisata } \\
\text { - Pengembangan dan } \\
\text { pembangunan objek wisata } \\
\text { yang ramah lingkungan. }\end{array}$ & $\begin{array}{l}\text { Strategi WT } \\
\text { - Mengoptimalkan promosi } \\
\text { dan memperbaiki program } \\
\text { pengembangan dengan } \\
\text { inovasi yang baru sehingga } \\
\text { siap untuk mengahadapi } \\
\text { persaingan antar objek } \\
\text { wisata. } \\
\text { - Meningkatkan kualitas } \\
\text { profesional manajemen } \\
\text { target pariwisata dan } \\
\text { mengurangi kerusakan } \\
\text { lingkungan yang disebabkan } \\
\text { oleh pembangunan asal- } \\
\text { asalan. }\end{array}$ \\
\hline
\end{tabular}

Berdasarkan hasil analisis SWOT di hasilkan strategi alternatif pengembangan kawasan Ekowisata Desa Bendosari yang dapat disajikan pada tabel berikut.

Tabel 3. Ranking Strategi Alternatif Pengembangan Kawasan Ekowisata Desa Bendosari

\begin{tabular}{|c|c|c|c|}
\hline $\begin{array}{l}\text { Strategi } \\
\text { Alternatif }\end{array}$ & Unsur Strategi & Keterkaitan & Skor \\
\hline \multicolumn{4}{|c|}{ Strategi SO } \\
\hline Strategi 1 & Memaksimalkan pengembangan paket ekowisata & S1, S2, S3, S6, S9, O3, O4, 05 & 2,624 \\
\hline Strategi ॥ & $\begin{array}{l}\text { Memberdayakan masyarakat lokal dalam kegiatan } \\
\text { ekowisata }\end{array}$ & $\mathrm{S} 1, \mathrm{~S} 2, \mathrm{~S} 3, \mathrm{O} 1, \mathrm{O} 2$ & 1,812 \\
\hline $\begin{array}{l}\text { Strategi } \\
\text { III }\end{array}$ & $\begin{array}{l}\text { Meningkatkan keamanan di objek wisata guna menjaga } \\
\text { kenyamanan serta menarik pengunjung }\end{array}$ & S4, S5, S6, S7, S9, O3, O5 & 1,734 \\
\hline $\begin{array}{l}\text { Strategi } \\
\text { IV }\end{array}$ & $\begin{array}{l}\text { Memaksimalkan pengelolaan potensi wisata untuk } \\
\text { meningkatkan pendapatan masyarakat }\end{array}$ & $\mathrm{S} 1, \mathrm{~S} 2, \mathrm{~S} 3, \mathrm{~S} 8, \mathrm{O} 2$ & 1,550 \\
\hline Strategi V & $\begin{array}{l}\text { menggunakan otonomi daerah dalam mengelola } \\
\text { kemampuan alam serta objek wisata yang menarik. }\end{array}$ & $\mathrm{S} 1, \mathrm{~S} 2, \mathrm{~S} 3, \mathrm{~S} 4, \mathrm{O} 1$ & 1,519 \\
\hline \multicolumn{4}{|c|}{ Strategi WO } \\
\hline $\begin{array}{l}\text { Strategi } \\
\text { XIII }\end{array}$ & $\begin{array}{l}\text { Mengadakan kerjasama antara investor dengan } \\
\text { pemerintah untuk mendukung peningkatan wisata yang } \\
\text { aman dari penyakit Covid } 19 \text {. }\end{array}$ & W2, W4, 01 & 0,849 \\
\hline Strategi $X$ & $\begin{array}{l}\text { Jangkauan yang cukup jauh dari Pusat Kota Malang bisa } \\
\text { dicapai dengan perbaikan jalan yang rusak dan didukung } \\
\text { oleh akomodasi dan daya tarik wisata Kota Batu. }\end{array}$ & W1, 04, 05 & 1,190 \\
\hline $\begin{array}{l}\text { Strategi } \\
\text { IX }\end{array}$ & $\begin{array}{l}\text { Penyuluhan tentang usaha-usaha yang terkait dengan } \\
\text { wisata terhadap SDM setempat. }\end{array}$ & W3, W6, 01, O2 & 1,216 \\
\hline $\begin{array}{c}\text { Strategi } \\
\quad \text { XII }\end{array}$ & Meningkatkan promosi wisata & W5, 03, 05 & 1,122 \\
\hline \multicolumn{4}{|l|}{ Strategi ST } \\
\hline $\begin{array}{l}\text { Strategi } \\
\quad V I\end{array}$ & $\begin{array}{l}\text { Mengoptimalkan keunikan sumber daya alam dan } \\
\text { potensi pariwisata harus menghadapi persaingan antar } \\
\text { objek wisata }\end{array}$ & $\mathrm{S} 1, \mathrm{~S} 2, \mathrm{~S} 3, \mathrm{~T} 2$ & 1,466 \\
\hline $\begin{array}{c}\text { Strategi } \\
\text { VII }\end{array}$ & $\begin{array}{l}\text { Mengembangkan dan membangun objek wisata yang } \\
\text { ramah lingkungan. }\end{array}$ & S3, S4, T3, T4 & 1,440 \\
\hline
\end{tabular}




\begin{tabular}{|c|c|c|c|}
\hline $\begin{array}{l}\text { Strategi } \\
\text { Alternatif }\end{array}$ & Unsur Strategi & Keterkaitan & Skor \\
\hline \multicolumn{4}{|c|}{ Strategi WT } \\
\hline $\begin{array}{l}\text { Strategi } \\
\text { VIII }\end{array}$ & $\begin{array}{l}\text { Mengoptimalkan promosi serta memperbaiki program } \\
\text { pengembangan dengan terobosan baru sehingga siap } \\
\text { mengahadapi persaingan dengan objek wisata lain. }\end{array}$ & W2, W4, W5, T2 & 1,278 \\
\hline $\begin{array}{l}\text { Strategi } \\
\text { XI }\end{array}$ & $\begin{array}{l}\text { Meningkatkan kualitas profesional manajemen target } \\
\text { pariwisata dan mengurangi kerusakan lingkungan yang } \\
\text { disebabkan oleh pembangunan asal-asalan. }\end{array}$ & W3, T3, T4 & 1,128 \\
\hline
\end{tabular}

Berdasarkan tabel 3 maka dipilih lima strategi alternatif dalam pengembangan ekowisata Desa Bendosari berdasarkan total skor yang diperoleh. Adapun strategi alternatif pengembangan ekowisata Desa Bendosari yang meliputi:

1. Memaksimalkan pengembangan paket ekowisata.

Paket wisata yang diusulkan dirancang secara alami dengan memanfaatkan pemandangan alam Desa Bendosari, dan aktivitas masyarakat di sektor pertanian dan peternakan. Sejalan dengan pendapat Fidaus dan Tutri (2017) bahwa pengelolaannya dilakukan secara sederhana yang lebih dominan adalah pemeliharaan keaslian lingkungan tanpa merusak alam, flora, dan fauna.

2. Memberdayakan masyarakat lokal dalam kegiatan ekowisata

Salah satu konsep pengembangan ekowisata bertujuan untuk meningkatkan partisipasi masyarakat dalam pengelolaannya sehingga dapat memberikan manfaat bagi perekonomian masyarakat setempat. Hal ini untuk membangun jembatan antara keinginan wisatawan dan konsep pengembangan ekowisata. Menurut Wahyuni (2015), masyarakat lokal sebenarnya bukan penghambat pengembangan ekowisata, karena perannya tidak boleh dipisahkan dalam proyek pariwisata. Pengelolaan berbasis masyarakat semacam ini merupakan salah satu metode pengelolaan alam yang mengambil pengetahuan dan kesadaran lingkungan masyarakat setempat sebagai dasar pengelolaannya.

3. Meningkatkan keamanan tempat wisata untuk menjaga kenyamanan dan menarik wisatawan. Lingkungan ekowisata yang bersih dan terawat serta aman menjadi salah satu alternatif untuk menarik wisatawan yang berkunjung agar wisatawan dapat merasa nyaman dan aman.

4. Memaksimalkan pengelolaan potensi wisata untuk meningkatkan pendapatan masyarakat Pengembangan ekowisata berpengaruh terhadap kesejahteraan masyarakat Desa Bendosari. Dengan berkembangnya kawasan ekowisata, dapat memberikan kesempatan kerja bagi masyarakat setempat, sehingga mendukung peningkatan pendapatan masyarakat, pendidikan dan kesejahteraan kesehatan.

5. Menggunakan otonomi daerah dalam mengelola kemampuan alam serta objek wisata yang menarik.

Peningkatan potensi bagian pariwisata seringkali dikaitkan dengan permintaan dan menjadi penyumbang pendapatan daerah, apalagi dengan adanya otonomi daerah, berbagai daerah berlomba-lomba untuk memanfaatkan dan mengembangkan potensinya. Potensi memberikan nilai tambah bagi pendapatan daerah atau pariwisata pada umumnya lebih difokuskan pada upaya peningkatan kontribusinya terhadap pendapatan asli daerah (PAD). Pengembangan pariwisata Desa Bendosari diatur sepenuhnya dalam Peraturan Daerah Kabupaten Malang Nomor 3 Tahun 2010 tentang Penataan Ruang Kabupaten Malang dan Rencana Pembangunan Jangka Menengah Daerah (RPJMD) Kabupaten Malang 2010-2015 telah ditetapkan dan disepakati bersama oleh pemerintah dan pemangku kepentingan pembangunan untuk mewujudkan Kabupaten Malang menjadi bumi Agro-wisata pertanian unggulan di Jawa Timur. 


\section{Simpulan}

Dari hasil dan pembahasan di atas dapat disimpulkan bahwa 1) Potensi sumber daya alam yang ada di area ekowisata Desa Bendosari yaitu potensi flora dan fauna, potensi wisata alam, potensi wisata pendidikan, potensi wisata kerajinan dan potensi wisata budaya. Dari perpaduan alam, flora dan fauna, keadaan kemasyarakatan serta adat istiadat yang tetap terjaga sangat tepat untuk dipelihara sebagai area wisata alam yang ramah lingkungan. Permasalahan ekowisata di Desa Bendosari diantaranya meliputi rendahnya kualitas SDM (sumber daya manusia), dana terbatas dan Pemerintah Kabupaten Malang tidak aktif membantu pengadaan sarana dan prasarana aktivitas ekowisata, juga tidak memberikan anggaran dana yang diprakarsai oleh pemerintah Desa Bendosari. 2) Ekowisata Desa Bendosari cocok dikembangkan menjadi suatu objek wisata melalui hasil pertimbangan berdasarkan Pedoman ADOODTWA (Analisis Daerah Operasi Objek dan Daya Tarik Wisata Alam) sebesar 87,71\%. 3) Strategi pengembangan kawasan Ekowisata Desa Bendosari adalah strategi expansion (mendukung strategi ofensif) dengan alternatif strategi yang meliputi: memaksimalkan pengembangan paket ekowisata, memberdayakan masyarakat lokal dalam kegiatan ekowisata, meningkatkan keamanan di objek wisata guna menjaga kenyamanan dan menarik pengunjung, memaksimalkan pengelolaan potensi wisata untuk meningkatkan pendapatan masyarakat dan menggunakan otonomi daerah dalam mengelola kemampuan alam serta objek wisata yang menarik.

\section{Daftar Pustaka}

Devy, H. A \& Soemanto, R. B. (2017). Pengembangan Obyek dan Daya Tarik Wisata Alam sebagai Daerah Tujuan Wisata di Kabupaten Karanganyar, FISIP UNS : Jurnal Sosiologi DILEMA 32 (1).

Direktorat Jenderal Perlindungan Hutan dan Konservasi Alam. (2003). Pedoman Analisis Daerah Operasi Obyek dan Daya Tarik Wisata Alam (ADOODTWA). Direktorat Wisata Alam dan Pemanfaatan Jasa Lingkungan Direktorat Jendral Perlindungan Hutan dan Konservasi Alam Departemen Kehutanan. Bogor.

Firdaus, Tutri, R. (2017). Potensi Pengembangan Ekowisata Di Nagari Kotobaru, Kecamatan X Koto, Kabupaten Tanah Datar Sumatera Barat. kawistara. Vol 7, No. 2, Hal. 115-206. ISSN 23555777 (Online)

Ginting, I A,. Panata P., Rahmawati. (2015). Penilaian dan Pengembangan Potensi Objek dan Daya Tarik Wisata Alam di Taman Wisata Alam (TWA) Sibolangit. Jurnal. Universitas Sumatera Utara Medan.

Hermawan, H. (2017). Pengaruh Atraksi Wisata, Keamanan dan Fasilitas Wisata Terhadap Kepuasan dan Pengaruhnya Terhadap Loyalitas Wisatawan. 15: 16.

Kesuma, A. I. t.t. "Membangun Ekowisata Dan Ekonomi Kreatif Berbasis Masyarakat Dan Kearifan Lokal Dalam Menghadapi Masyarakat Ekonomi Asean," 11.

MacKinnon JK, Child, J Thorsell. (1986). Pengelolaan Kawasan yang dilindungi di Daerah Tropika (Terjemahan). 1990. Gadjah Mada University Press. Yogyakarta.

Sihite RY, Agus S, Bainah SD. (2018). Unit XIII KPH Gunung Rajabasa, Way Pisang, Batu Serob Lampung berpotensi menjadi target wisata alam prioritas. Majalah Sylva Lestari, 6(2): 84-93.

Sirega, Y. C. (2017). "Fasilitas Pada Ekowisata Danau Naga Sakti Di Kabupaten Siak Sri Indrapura Riau" 4: 11.

TIES. (2015). Retrievedfrom The International Ecotourism Society: http://www.ecotuorism.org/what-isecotourism.

Tosun, Cevat., Timothy, Dallen J. (2003). Arguments for Community Participation in the Tourism Development Process. The Journal Of Tourism Studies 14: 1-15.

Wahyuni, S., Sulardiono, B.,, Hendrarto. B. (2015). Strategi Pengembangan Ekowisata Mangrove Wonorejo, Kecamatan Rungkut Surabaya. Diponegoro Journal Of Maquares. Vol 4, No. 4, Hal. 66-70. 